\title{
Multivariate Approach in the Initial Development of Soybean as a Function of Co-inoculation and Micronutrients
}

\author{
Paloma Helena da Silva Libório ${ }^{1}$, Ivana Marino Bárbaro-Torneli ${ }^{2}$, Fabio Olivieri de Nobile ${ }^{3}$, \\ Fabiana Mota da Silva ${ }^{1} \&$ Sandra Helena Unêda-Trevisoli ${ }^{1}$ \\ ${ }^{1}$ Departamento de Produção Vegetal, Universidade Estadual Paulista, Jaboticabal, São Paulo, Brazil \\ ${ }^{2}$ Agência Paulista de Tecnologia dos Agronegócios, Polo Regional Alta Mogiana, Colina, São Paulo, Brazil \\ ${ }^{3}$ Centro Universitário da Fundação Educacional de Barretos, Barretos, São Paulo, Brazil \\ Correspondence: Paloma Helena da Silva Libório, Departamento de Produção Vegetal, Universidade Estadual \\ Paulista, Via de Acesso Prof. Paulo Donato Castellane, s/n, 14884-900, Jaboticabal, São Paulo, Brazil. E-mail: \\ paloma_liborio@hotmail.com
}

Received: April 15, 2019

doi:10.5539/jas.v12n3p165

\author{
Accepted: January 10, 2020 \\ Online Published: February 15, 2020 \\ URL: https://doi.org/10.5539/jas.v12n3p165
}

\begin{abstract}
Co-inoculation in soybean is the mixed inoculation with bacterias of the genus Bradyrhizobium and Azospirillum brasilense. The applicability of this practice has become the subject of recent research that aims to overcome the main limitations of biological nitrogen fixation, obtained by traditional soybean inoculation with only Bradyrhizobium. This study investigated the interaction effects among cultivars, bacterium types, with and without micronutrients applied to the seeds on the initial developmental stages of soybean cultivars using multivariate analyses. The seedlings were cultivated in pots filled with soil in greenhouse conditions. The experiment was installed in the Alta Mogiana branch of the Paulista Agribusiness Technology Agency (APTA) in Colina, SP. The 32 treatments were arranged as $4 \times 4 \times 2$ factorial with four soybean cultivars, four bacterium types, with and without micronutrients applied to the seeds. The evaluations were performed at 5,8 and 32 days after sowing (DAS). The parameters analyzed in the pots showed that the cultivars behaved differently depending on the type of bacteria used. The co-inoculation promoted better nodulation and initial seedling growth in some cultivars. In general, cultivars without application of micronutrients were superior in terms of the parameters analyzed.
\end{abstract}

Keywords: Azospirillum, cluster analysis, cultivars, Glycine $\max (\mathrm{L}$.$) , mixed inoculation$

\section{Introduction}

The soybean [Glycine max (L.) Merril] culture is among the most important cultures worldwide while being the main Brazilian commodity as well. The world production reached 369.32 million tons, with the United States and Brazil being the largest producers (USDA, 2018). In the 2018/19 harvest, Brazilian average yield was 3,182 $\mathrm{kg} \mathrm{ha}^{-1}$ for a cultivated area of 35.8 million hectares (CONAB, 2019).

The soybean crop contributes significantly to the improvement of the productive systems since nitrogen is supplied to the soil via biological nitrogen fixation (BNF) besides the economic benefits generated by the grain production. Soybean is the best example in Brazil for the economic benefits provided by BNF since it generates an economy of approximately US\$ 15 billion. In the countries where investment in research was not as strong, the biological process can only supply $50 \%$ of the demand, being complemented with nitrogen fertilization (Hungria et al., 2007).

Initially, the used turfus-type inoculants combined two of the four strains: Bradyrhizobium elkanii SEMIA 587 and SEMIA 5019 (29w), as well as B. japonicum SEMIA 5079 (CPAC-15) and SEMIA 5080 (CPAC-7) (Zilli et al., 2006; Santana et al., 2011). As the research advanced, liquid-type inoculants that are recommended for application in the sowing groove to avoid contact with other products have been developed and applied to the seeds (Santana et al., 2011).

Therefore, soybean cultivation is only economically feasible due to the inoculants containing Bradyrhizobium strains. The procedure should be done annually to maximize the benefits provided by the microorganisms, resulting in average yield increases of about $8 \%$ (Hungria \& Nogueira, 2013). 
Recent research on new technology for soybean culture has recommended using co-inoculation, which consists of adding more than one microorganism (Azospirillum brasilense) recognized as beneficial to the plants to maximize the gains obtained with BNF (Bárbaro et al., 2011; Hungria et al., 2013).

Also, to maximize the biological nitrogen fixation in soybean and increase yield, research to identify traits that help selecting more efficient genotypes regarding their symbiotic capacity should be considered by breeding programs. Therefore, it becomes necessary to understand better the interactions among different genotypes and bacteria involved in the process (Bárbaro et al., 2009). The multivariate analysis techniques are important tools for this type of study and have been widely used for the genetic analysis of the relationship between traits and existing genetic material (Iqbal et al., 2008). It is also noteworthy the need for research regarding the co-inoculation practice that has been recently confirmed as agronomical efficient in Brazil but the results in the literature still vary greatly (Gitti et al., 2012; Hungria et al., 2013; Zuffo et al., 2015; Zuffo et al., 2016).

This study evaluated the effects of the interaction among soybean cultivars, bacterium types with and without micronutrients on the early developmental stages of seedlings, using multivariate analyzes.

\section{Materials and Methods}

\subsection{Description of the Experiment}

Soil samples were collected from the experimental area cultivated with soybean in the Alta Mogiana branch of APTA, in Colina, SP. The soil samples were submitted to physico-chemical analysis, and counting of Bradyrhizobium bacteria and soil associative diazotrophic bacteria. The bacterial counts were performed in the Agricultural Microbiology Laboratory of UNESP, FCAV, in Jaboticabal, SP, following the recommendations of Dobereiner et al. (1995), and the results are detailed in Table 1.

Table 1. Results of the Bradyrhizobium and diazotrophic bacteria counts for the soil of the experimental area of APTA, Colina, SP, in the 2015/16 harvest

\begin{tabular}{llllc}
\hline Sample & Soil moisture & Total bacteria & Bradyrhizobium & Diazotrophic Bacteria \\
\hline & $\%$ & $--------------------\mathrm{CFU} \mathrm{g}^{-1}$ & dry soil \\
\hline APTA & 11.63 & $8.23 \times 10^{6}$ & $2.14 \times 10^{7}$ & $1.1 \times 10^{6}$ \\
\hline
\end{tabular}

Note. CFU: Colony Forming Unit.

The soil of the experimental area is a dystrophic Red Latosol. The results of the chemical and physical soil analysis are as follows: $\mathrm{pH}\left(\mathrm{CaCl}_{2}\right)=5.21 ; \mathrm{M} . \mathrm{O} .=22.50 \mathrm{~g} \mathrm{dm}^{-3} ; \mathrm{CO}=13 \mathrm{~g} \mathrm{dm}^{-3} ; \mathrm{P}=18.54 \mathrm{mg} \mathrm{dm}^{-3} ; \mathrm{K}=3.04$ mmolc dm ${ }^{-3} ; \mathrm{Ca}=18.67 \mathrm{mmolc} \mathrm{dm}^{-3} ; \mathrm{Mg}=12.86 \mathrm{mmolc} \mathrm{dm}^{-3} ; \mathrm{H}+\mathrm{Al}=27.46 \mathrm{mmolc} \mathrm{dm}^{-3} ; \mathrm{SB}=34.58 \mathrm{mmolc}$ $\mathrm{dm}^{-3} ; \mathrm{CTC}=62.04 \mathrm{mmolc} \mathrm{dm}^{-3}$, and $\mathrm{V}=55.73 \%, \mathrm{~S}=3.57 \mathrm{mg} \mathrm{dm}^{-3}, \mathrm{Zn}=0.70 \mathrm{mg} \mathrm{dm}^{-3}, \mathrm{~B}=0.18 \mathrm{mg} \mathrm{dm}^{-3}, \mathrm{Mn}$ $=12.70 \mathrm{mg} \mathrm{dm}^{-3}, \mathrm{Cu}=0.45 \mathrm{mg} \mathrm{dm}^{-3}, \mathrm{Fe}=30.81 \mathrm{mg} \mathrm{dm}^{-3}$; total sand $=804 \mathrm{~g} \mathrm{~kg}$ soil; clay $=150 \mathrm{~g} \mathrm{~kg} \mathrm{soil}$, and silt $=45 \mathrm{~g} \mathrm{~kg}$ soil, expressed as percentage: total sand $=80.40 \%$ (coarse sand $=55.50 \%+$ fine sand $=24.90 \%$ ); clay $=15.00 \%$, and silt $=4.50$.

\subsection{Material Used and Experimental Conduction}

The soybean seedlings were planted in pots filled with the soil in the greenhouse in the Alta Mogiana branch of the Paulista Agribusiness Technology Agency (APTA). The 5-L plastic pots were filled with the properly corrected soil from the experimental area already cultivated with soybean. The soil was fertilized with N-P-K (4-20-20) at dosages calculated according to the chemical analysis of the soil.

The treatments were arranged as $4 \times 4 \times 2$ factorial with four commercial cultivars of soybean: Brasmax Flecha IPRO, BMX Potencia RR, 5D634 RR and NS7338 IPRO, four types of bacteria [Control, Bradyrhizobium (traditional inoculation), Azospirillum and Bradyrhizobium + Azospirillum (Co-inoculation)], with and without cobalt and molybdenum micronutrients applied to the seeds, see Table 2. 
Table 2. The 32 treatments investigated regarding the interactions among cultivars, types of bacteria with and without micronutrients

\begin{tabular}{|c|c|c|c|}
\hline Treatment & Cultivar & Bacteria type & Micronutrients \\
\hline 1 & Brasmax Flecha IPRO & Control & Without \\
\hline 2 & Brasmax Flecha IPRO & Control & With \\
\hline 3 & Brasmax Flecha IPRO & Bradyrhizobium & Without \\
\hline 4 & Brasmax Flecha IPRO & Bradyrhizobium & With \\
\hline 5 & Brasmax Flecha IPRO & Azospirillum & Without \\
\hline 6 & Brasmax Flecha IPRO & Azospirillum & With \\
\hline 7 & Brasmax Flecha IPRO & Brady + Azos & Without \\
\hline 8 & Brasmax Flecha IPRO & Brady + Azos & With \\
\hline 9 & BMX Potência RR & Control & Without \\
\hline 10 & BMX Potência RR & Control & With \\
\hline 11 & BMX Potência RR & Bradyrhizobium & Without \\
\hline 12 & BMX Potência RR & Bradyrhizobium & With \\
\hline 13 & BMX Potência RR & Azospirillum & Without \\
\hline 14 & BMX Potência RR & Azospirillum & With \\
\hline 15 & BMX Potência RR & Brady + Azos & Without \\
\hline 16 & BMX Potência RR & Brady + Azos & With \\
\hline 17 & 5D634 RR & Control & Without \\
\hline 18 & 5D634 RR & Control & With \\
\hline 19 & 5D634 RR & Bradyrhizobium & Without \\
\hline 20 & 5D634 RR & Bradyrhizobium & With \\
\hline 21 & 5D634 RR & Azospirillum & Without \\
\hline 22 & 5D634 RR & Azospirillum & With \\
\hline 23 & 5D634 RR & Brady + Azos & Without \\
\hline 24 & 5D634 RR & Brady + Azos & With \\
\hline 25 & NS 7338 IPRO & Control & Without \\
\hline 26 & NS 7338 IPRO & Control & With \\
\hline 27 & NS 7338 IPRO & Bradyrhizobium & Without \\
\hline 28 & NS 7338 IPRO & Bradyrhizobium & With \\
\hline 29 & NS 7338 IPRO & Azospirillum & Without \\
\hline 30 & NS 7338 IPRO & Azospirillum & With \\
\hline 31 & NS 7338 IPRO & Brady + Azos & Without \\
\hline 32 & NS 7338 IPRO & Brady + Azos & With \\
\hline
\end{tabular}

The experiment was arranged as a randomized complete block design with the experimental plot being one pot with 8 seedlings, with four repetitions.

The seeds were treated with commercial liquid inoculants used in soybean culture at the following doses, 60 $\mathrm{mL} / 50 \mathrm{~kg}$ seed of Biomax ${ }^{\circledR}$ Premium with Bradyrhizobium and $150 \mathrm{~mL} / 20 \mathrm{~kg}$ seed of Biomax ${ }^{\circledR}$ Premium Maize with Azospirillum brasilense for grasses, as recommended by the manufacturer. Half the dose of both inoculants was used in the co-inoculation of seeds. A dose of $100 \mathrm{~mL} \mathrm{ha}^{-1}$ of the product containing $1.5 \% \mathrm{Co}$ and $15 \% \mathrm{Mo}$ micronutrients was applied to the seeds before the inoculation.

A few days before sowing, all seeds were treated with $2 \mathrm{~mL} / \mathrm{kg}$ seed of the Standak Top insecticide/fungicide, whereas the inoculants were applied last on the sowing day. In addition, some precautions were taken to ensure greater efficiency of inoculants, such as seed inoculation performed in the shade while the inoculant was uniformly distributed on all seeds.

\subsection{Evaluations}

At 5 and 8 days after sowing (DAS) following the recommendations of Brazil (2009), we evaluated the percent germination as well as the mass (MSR and MSPA) and length (CR and CPA) of the root and aerial shoot expressed as $\mathrm{g} \mathrm{plant}^{-1}$ and $\mathrm{cm}$, respectively, at 8 DAS. The same parameters were also evaluated at $32 \mathrm{DAS}$, in addition to the number of nodes (NNOD) per plant ${ }^{-1}$ and node dry mass (MNNOD) per mg plant ${ }^{-1}$. 


\subsection{Statistical Analysis}

The multivariate exploratory analyses were used to evaluate the means in the present study. Initially, the data were standardized following the equation $Z_{i j}=X_{i j}-X_{j} / S_{j}$, where: $j=1,2, \ldots p$ traits; $i=1,2, \ldots n$, objects; $X_{j}$ and $S_{j}=$ mean and standard deviation of column $\mathrm{j}$. Subsequently, two exploratory approaches were studied: principal component and non-hierarchical cluster analysis by the k-means method. The similarity between treatments was measured by the Euclidean distance and the mean binding/linkage between the clusters was performed by the Ward method, to determine the number of clusters previously. In the principal component analysis, the eigenvalues were extracted from the covariance matrix that generated the eigenvectors called principal components, which are determined from the characteristic equation of the matrix (Ferraudo, 2014).

For calculating the principal components, the variability was decomposed into four eigenvectors (principal components) constructed with the eigenvalues of the covariance matrix, which are linear combinations of the original variables seeking to maximize the relevant information (Hair et al., 2009).

For calculating the proportion of the total variance assigned to each principal component, we have the expression: $\mathrm{CP}_{\mathrm{h}}=\lambda_{\mathrm{h}} /$ trace (C) 100, where, $\mathrm{C}=$ covariance matrix of the standardized original data; $\chi_{\mathrm{h}}=\mathrm{h}$-th characteristic root (eigenvalue) of Matrix $C$, Trace $(C)=\chi 1+\chi 2 \ldots+\chi h$. Only eigenvalues $\geq 1$ are considered since these components carry relevant amount of information from the original variables. On the other hand, eigenvalues $<1$ have no relevant amount of information in the component. The correlation between traits/parameters and principal components was calculated using the equation: $r_{x j}\left(C_{h}\right)=a_{i h} \sqrt{ } \lambda_{h} / S_{j}$, where: $S_{j}=$ standard deviation of the variable $\mathrm{j} ; \mathrm{a}_{\mathrm{ih}}=$ coefficient of the variable $\mathrm{j}$ in the $\mathrm{h}$-th principal component; $\chi_{\mathrm{h}}=\mathrm{h}$-th characteristic root (eigenvalue) of the covariance matrix (Kaiser, 1958).

The non-hierarchical cluster analysis of the variables evaluated in the pots by the k-means method used a number of clusters previously determined for the calculation of the points representing the cluster centroids: $\mathrm{E}=$ $\Sigma_{\mathrm{k}=1}^{\mathrm{k}} \Sigma_{\mathrm{x} I \mathrm{Eck}} \mathrm{d}\left(\mathrm{x}_{\mathrm{i}}, \mathrm{x}_{\mathrm{ok}}\right)$, where, $\mathrm{x}_{\mathrm{ok}}=$ cluster centroid $\mathrm{Ck} ; \mathrm{d}\left(\mathrm{xi}, \mathrm{x}_{\mathrm{ok}}\right)=$ distance between points $\mathrm{x}_{\mathrm{i}}$ and $\mathrm{x}_{\mathrm{ok}}$. The centroid can be either the mean or median of a group of points. The objective of k-means is to minimize the distance between each point and its centroid (Hair et al., 2009). All multivariate analyses were performed using Statistica software, version 10 (Stasoft, 2010).

\section{Results and Discussion}

Principal components analysis resulted in four principal components (PC), which explained $80.74 \%$ of the variance (Table 3).

Table 3. Eigenvector matrix and statistics of the twelve traits evaluated as a response to the interaction among cultivars, bacterium types with and without micronutrients, planted in pots and cultivated in the greenhouse

\begin{tabular}{lllll}
\hline Eigenvalue number & Eigenvalue & Total Variance (\%) & Accumulated eigenvalue & Cumulative variance (\%) \\
\hline 1 & 4.277 & 35.640 & 4.277 & 35.640 \\
2 & 2.284 & 19.036 & 6.561 & 54.677 \\
3 & 1.893 & 15.776 & 8.454 & 70.453 \\
4 & 1.234 & 10.285 & 9.689 & 80.738 \\
5 & 0.704 & 5.867 & 10.393 & 86.605 \\
6 & 0.580 & 4.833 & 10.973 & 91.438 \\
7 & 0.335 & 2.789 & 11.307 & 94.227 \\
8 & 0.226 & 1.887 & 11.534 & 96.114 \\
9 & 0.193 & 1.610 & 11.727 & 97.724 \\
10 & 0.155 & 1.295 & 11.882 & 99.020 \\
11 & 0.093 & 0.772 & 11.975 & 99.792 \\
12 & 0.025 & 0.208 & 12.000 & 100.000 \\
\hline
\end{tabular}

The most important variables in discriminating PC1 treatments were CR32, MSPA32, MSR32, CPA8, CR8, MSR8 and G5, followed by PC2 with MSPA8, G5 and G8. The PC3 was explained by nodulation and PC4 by CPA 32 (Tables 3 and 4). Thus, all studied traits were correlated with the four principal components, becoming important to evaluate the initial development of soybean in this work. Toller et al. (2009) evaluated the parameters of BNF in 15 conventional soybean cultivars and reported higher node numbers and nodular dry matter for the cultivars IAC 23 and M-SOY5942. The cultivars BRS 133 and BRS 184 were highlighted for the 
root dry mass whereas BRS 184, for the aerial shoot dry mass. The best correlation estimates were obtained for number of nodes $\mathrm{x}$ nodular dry mass and root dry mass $\mathrm{x}$ aerial shoot dry mass.

Table 4. Correlation coefficients between the traits and the four principal components that retained the greatest amount of information relevant to the studied treatments

\begin{tabular}{lllll}
\hline Traits & CP1 & CP2 & CP3 & CP4 \\
\hline CPA32 & -0.417 & 0.008 & -0.273 & -0.772 \\
CR32 & -0.651 & -0.114 & -0.303 & -0.451 \\
NNOD32 & -0.192 & -0.210 & -0.843 & 0.149 \\
MSPA32 & 0.794 & 0.420 & -0.179 & -0.072 \\
MSR32 & 0.833 & 0.370 & -0.054 & -0.032 \\
MNOD32 & -0.230 & -0.243 & -0.728 & 0.466 \\
CPA8 & -0.840 & 0.201 & 0.290 & 0.021 \\
CR8 & 0.630 & 0.529 & -0.096 & -0.236 \\
MSPA8 & 0.116 & 0.720 & -0.569 & -0.013 \\
MSR8 & -0.667 & 0.465 & -0.081 & -0.090 \\
G5 & -0.624 & 0.605 & 0.106 & 0.194 \\
G8 & -0.561 & 0.657 & 0.128 & 0.298 \\
\hline
\end{tabular}

Note. G5 and G8 = germination percentage 5 and 8 DAS; CPA 8 and CPA $32=$ aerial shoot length; $\mathrm{CR} 8$ and CR $32=$ root length; MSPA8 and MSPA32 = aerial shoot dry mass; MSR8 and MSR32 = root dry mass; NNOD32 = number of nodes and MNOD32 = node dry mass.

Ferraudo (2014) defined as important the variables that have correlation values above 0.6 regardless of the signal, noting that correlations with equal signs indicate that the variables are positively correlated and those with different signs are negatively correlated. It is noteworthy that all the important traits in PC2 and PC3 are positively correlated, except for PC1 only, in which CR32, CPA8, MSR8 and G5 correlated positively with each other and inversely with the traits MSPA32, MSR32 and CR8.

The two-dimensional plane formed by the components PC1 (35.64\%) and PC2 (19.04\%) retained 54.68\% of the original variance (Figure 1). The treatments are distributed on a coordinate factor plan considering the relationship between the variables.

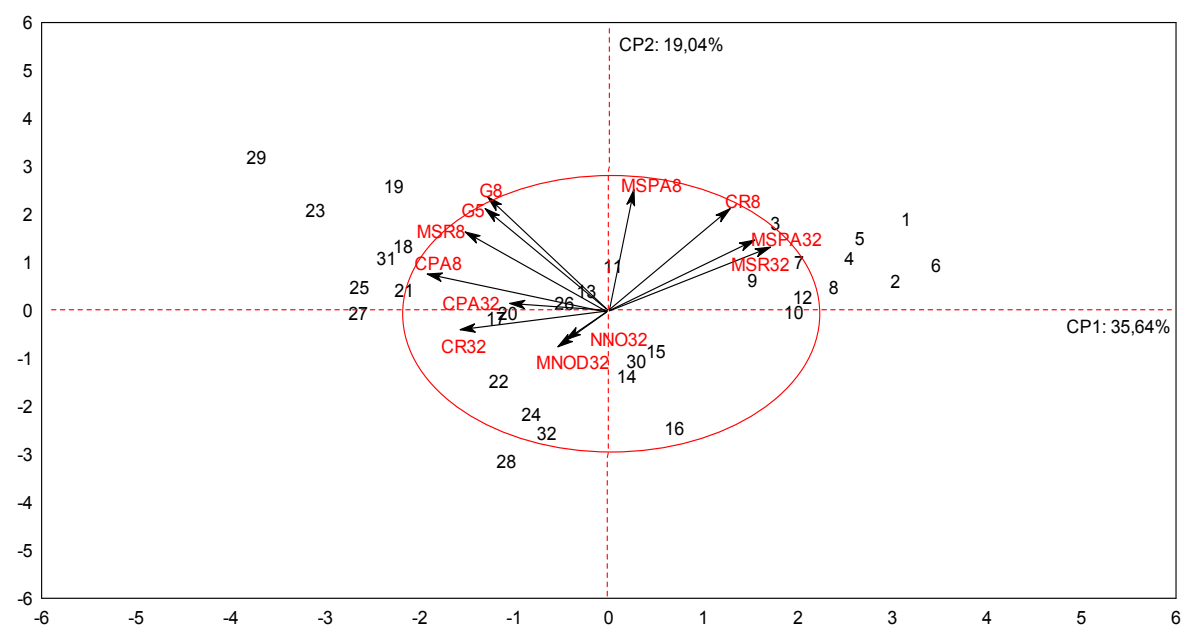

Figure 1. Biplot showing the dispersion of the 32 treatments using four soybean cultivars, four bacterium types, without and with micronutrients, for the principal components PC1 $\times$ PC2. G5 and G8 = germination percentage

5 and 8 DAS; CPA 8 and CPA32 = aerial shoot length; CR8 and CR32 = root length; MSPA8 and MSPA32 = aerial shoot dry mass; MSR8 and MSR32 = root dry mass; NNOD32 = number of nodes and MNOD32 $=$ node dry mass 
The treatments located in the center of the plane, within the limits of the pre-defined scales, are not significantly different from one another so that the traits cannot be characterized as superior to one another in this amplitude range, making the group homogeneous. However, greater specificity for G5, MSR8 and CPA8 was observed for treatments 29, 23, 25, 31, 18 and 19 corresponding to NS7338 IPRO (Azospirillum, without micronutrients), 5D634 RR (Brady + Azos, without micronutrients), NS7338 IPRO (Control, without micronutrients), NS 7338 IPRO (Brady + Azos, without micronutrients), 5D634 RR (Control, with micronutrients), 5D634 RR (Bradyrhizobium, without micronutrients), respectively. The 25-NS7338 IPRO (Control, without micronutrients) and 27-NS7338 IPRO (Bradyrhizobium, without micronutrients) treatments were more specific for the CPA32 and CR32 traits (Figure 1).

The MSPA32 and MSR32 were higher for the treatments 1-Brasmax Flecha IPRO (Control, without micronutrients), 2-Brasmax Flecha IPRO (Control, with micronutrients), 3-Brasmax Flecha IPRO (Bradyrhizobium, without micronutrients), 4-Brasmax Flecha IPRO (Bradyrhizobium, with micronutrients), 5-Brasmax Flecha IPRO (Azospirillum, without micronutrients), 6-Brasmax Flecha IPRO (Azospirillum, with micronutrients) and 8-Brasmax Flecha IPRO (Brady + Azos, with micronutrients) (Figure 1).

Likewise, Bohrer and Hungria (1998) reported marked differences among cultivars regarding nodulation potential and BNF and concluded that the amount of shoot dry mass is a good parameter for selecting the most promising soybean symbioses.

The two-dimensional plan $(\mathrm{PC} 1 \times \mathrm{PC} 3)$ retained $51.42 \%$ of the variance, with treatments $29-\mathrm{NS} 7338$ IPRO (Azospirillum, without micronutrients), 25-NS7338 IPRO (Control, without micronutrients), 18-5D634 RR (Control, with micronutrients), 21-5D634 RR (Azospirillum, without micronutrients), better discriminated for the CPA8 trait. The traits CR32, CPA32, NNOD32 and MNOD32 had the best results for the treatments 23-5D634 RR (Brady + Azos, without micronutrients), 27-NS7338 IPRO (Bradyrhizobium, without micronutrients), 31-NS7338 IPRO (Brady + Azos, without micronutrients) and 19-5D634 RR (Bradyrhizobium, without micronutrients) (Figure 2).

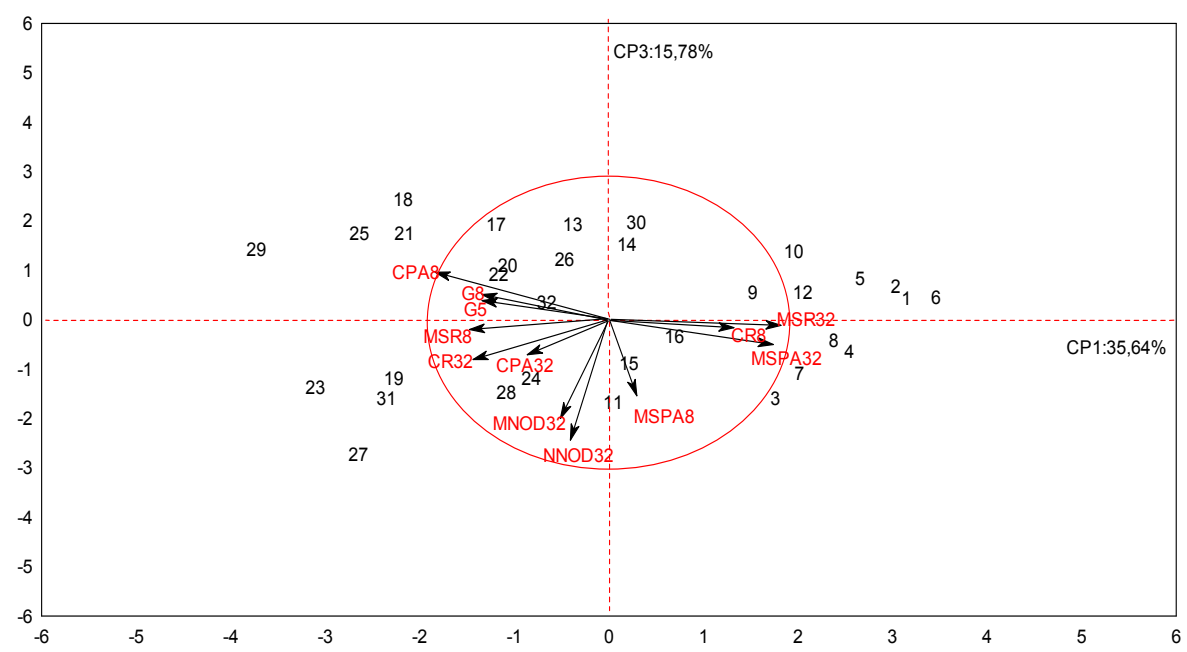

Figure 2. Biplot showing the dispersion of the 32 treatments with four soybean cultivars, four bacterium types, without and with micronutrients, for the principal components PC1 $\times$ PC3. G5 and G8 = germination percentage 5 and 8 DAS; CPA8 and CPA32 = aerial shoot length; CR8 and CR32 = root length; MSPA8 and MSPA32 = aerial shoot dry mass; MSR8 and MSR32 = root dry mass; NNOD32 = number of nodes and MNOD32 = node dry mass

The best results for MSR32 were observed for the treatments 10-BMX Potencia RR (Control, with micronutrients), 12-BMX Potencia RR (Bradyrhizobium, with micronutrients), 5-Brasmax Flecha IPRO (Azospirillum, without micronutrients), 2-Brasmax Flecha IPRO (Control, with micronutrients), 1-Brasmax Flecha IPRO (Control, without micronutrients), 6-Brasmax Flecha IPRO (Azospirillum, with micronutrients). The treatments 8-Brasmax Flecha IPRO (Brady + Azos, with micronutrients), 4-Brasmax Flecha IPRO (Bradyrhizobium, with micronutrients), 3-Brasmax Flecha IPRO (Bradyrhizobium, without micronutrients) and 
7-Brasmax Flecha IPRO (Brady + Azos, without micronutrients) were discriminated by CR8 and MSPA32 (Figure 2).

Finally, the two-dimensional plane formed by the components PC1 (35.64\%) and PC4 (10.29\%) retained 45.93\% of the original variance (Figure 3). Treatments 31-NS7338 IPRO (Brady + Azos, without micronutrients) and 18-5D634 RR (Control, with micronutrients) were more specific for G8 and G5, respectively. Whereas the treatments 29-NS7338 IPRO (Azospirillum, without micronutrients), 27-NS7338 IPRO (Bradyrhizobium, without micronutrients), 23-5D634 RR (Brady + Azos, without micronutrients), 25-NS7338 IPRO (Control, without micronutrients) and 19-5D634 RR (Bradyrhizobium, without micronutrients) were more specific for the traits CPA8, MSR8 and CR32.

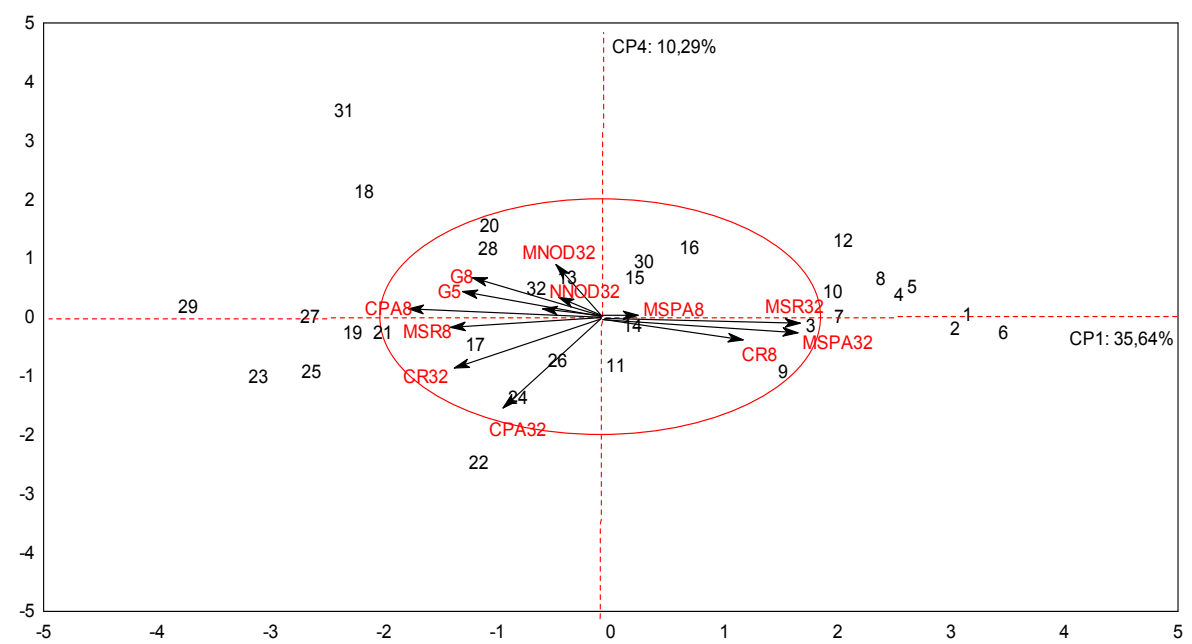

Figure 3. Biplot showing the dispersion of the 32 treatments using four soybean cultivars, four bacterium types, without and with micronutrients, in pots for the principal components $\mathrm{PC} 1 \times \mathrm{PC} 4$. G5 and G8 = germination percentage 5 and 8 DAS; CPA 8 and CPA32 = aerial shoot length; CR8 and CR32 = root length; MSPA 8 and MSPA32 = aerial shoot dry mass; MSR8 and MSR32 = root dry mass; NNOD32 = number of nodes and MNOD32 = node dry mass

For CPA32, the treatment 22-5D634 RR (Azospirillum, with micronutrients) was better discriminated. On the other hand, the treatments 12-BMX Potencia RR (Bradyrhizobium, with micronutrients), 8-Brasmax Flecha IPRO (Brady + Azos, with micronutrients), 10-BMX Potencia RR (Control, with micronutrients), 4-Brasmax Flecha IPRO (Bradyrhizobium, with micronutrients), 7-Brasmax Flecha IPRO (Brady + Azos, without micronutrients), 5-Brasmax Flecha IPRO (Azospirillum, without micronutrients), 2-Brasmax Flecha IPRO (Control, with micronutrients), 1-Brasmax Flecha IPRO (Control, without micronutrients), and 6-Brasmax Flecha IPRO (Azospirillum, with micronutrients) performed better for the traits MSR32 and MSPA32.

The great variability observed among soybean-nodulating strains, regarding the efficiency of the symbiotic process (Araújo \& Hungria, 1999), generates different interactions between bacteria and soybean genotypes (Bohrer \& Hungria, 1998), corroborating the results shown in the 3 dispersion biplots of the different treatments (Figures 1,2 and 3) in this work.

The 32 treatments and 12 traits evaluated previously by the Ward hierarchical clustering method formed nine clusters at the $18.18 \%$ cutoff limit in the dendogram, marked by abrupt level changes. This assumption was used in the non-hierarchical k-means method (Figure 4). 


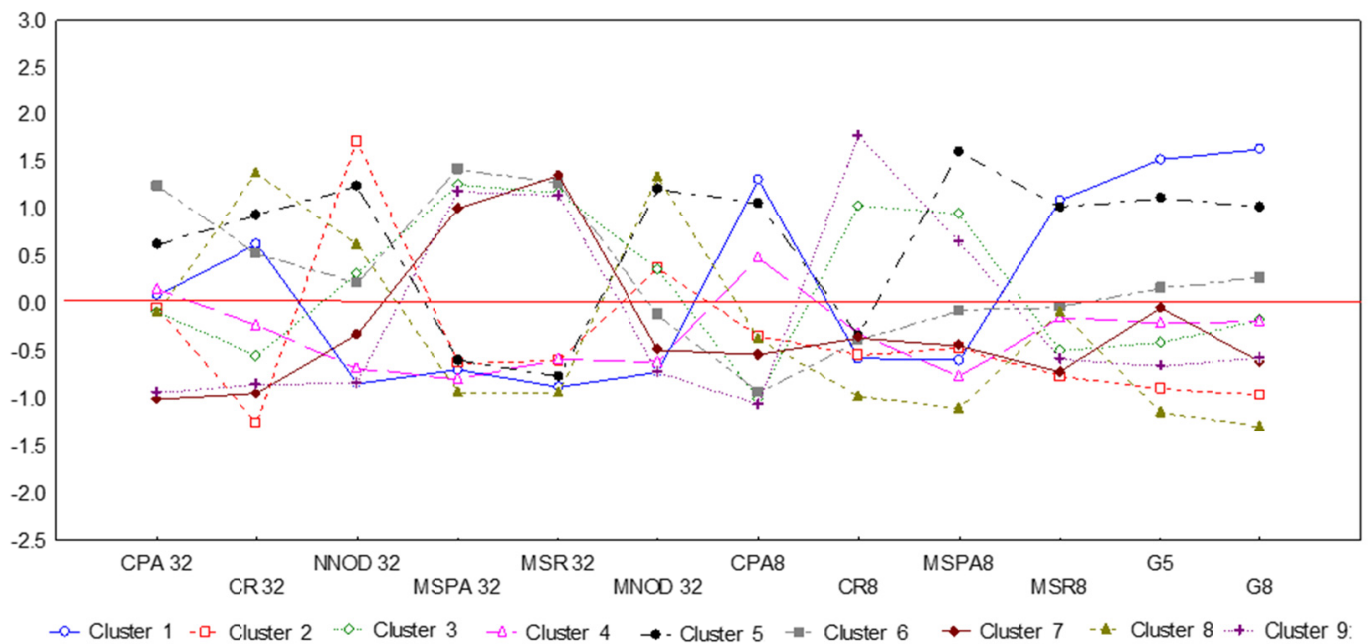

Figure 4. Distribution of the cluster centroids for the k- means clustering analysis obtained from the traits: G5 and G8 = germination percentage 5 and 8 DAS; CPA8 and CPA32 = aerial shoot length; CR8 and CR32= root length; MSPA8 and MSPA32 = aerial shoot dry mass; MSR8 and MSR32 = root dry mass; NNOD32= number of nodes and MNOD32 = node dry mass

Cluster 1 was formed by treatments 18-5D634 RR (Control, with micronutrients), 21-5D634 RR (Azospirillum, without micronutrients), 25-NS7338 IPRO (Control, without micronutrients), 29-NS7338 IPRO (Azospirillum, without micronutrients) and characterized by higher mean values of CPA32, CR32, CPA8, MSR8, G5 and G8 (Figure 4).

The treatment 15-BMX Potencia RR (Brady + Azos, without micronutrients) formed cluster 2, highlighting the nodulating parameters due to the high values of NNOD32 and MNOD32. Cluster 3 grouped the treatments 3-Brasmax Flecha IPRO (Bradyrhizobium, without micronutrients), 4-Brasmax Flecha IPRO (Bradyrhizobium, with micronutrients), 7-Brasmax Flecha IPRO (Brady + Azos, without micronutrients) and 8- Brasmax Flecha IPRO (Brady + Azos, with micronutrients), which was also characterized by CR8, MSPA8, MSPA32, MSR32, NNOD32 and MNOD32.

Cluster 4 grouped the treatments 13-BMX Potencia RR (Azospirillum, without micronutrients), 14-BMX Potencia RR (Azospirillum with micronutrients), 16-BMX Potencia RR (Brady + Azos, with micronutrients), 17-5D634RR (Control, without micronutrients), 20-5D634RR (Bradyrhizobium, with micronutrients), 22-5D634RR (Azospirillum, with micronutrients), 26-NS7338 IPRO (Control, with micronutrients) and 30-NS7338 IPRO (Azospirillum, with micronutrients) that displayed only CPA values slightly above average at 8 and 32 DAS.

Cluster 5, formed by the treatments 19-5D634RR (Bradyrhizobium, without micronutrients), 23-5D634RR (Brady + Azos, without micronutrients), 27- NS7338 IPRO (Bradyrhizobium, without micronutrients) and 31NS7338 IPRO (Brady + Azos, without micronutrients), had the best results since the values were above the average for most of the evaluated traits CPA32, CR32, NNOD32, MNOD32, CPA8, MSPA8, MSR8, G5 and G8.

The application of cobalt and molybdenum by way of seeds can dramatically affect the survival of bacteria in standard inoculation (Campo et al., 2010; Santana et al., 2011), the same being verified in cluster 5 for Azospirillum and co-inoculation.

Cluster 6 formed by treatments 9-BMX Potencia RR (Control, without micronutrients) and 11-BMX Potencia RR (Bradyrhizobium, without micronutrients) had better results for the traits CPA32, CR32, MSPA32 and MSR32 and values slightly above the mean for NNOD32, G5 and G8. Cluster 7 formed by 10-BMX Potencia RR (Control, with micronutrients) and 12-BMX Potencia RR (Bradyrhizobium, with micronutrients) was characterized by high MSPA32 and MSR32.

Cluster 8 was composed of treatments 24-5D634RR (Brady + Azos, with micronutrients), 28-NS7338 IPRO (Bradyrhizobium, with micronutrients) and 32-NS7338 IPRO (Brady + Azos, with micronutrients) that had high values of CR32, NNOD32 and MNOD32. Finally, cluster 9 grouped 1-Brasmax Flecha IPRO (Control, without micronutrients), 2-Brasmax Flecha IPRO (Control, with micronutrients), 5-Brasmax Flecha IPRO (Azospirillum, 
without micronutrients) and 6-Brasmax Flecha IPRO (Azospirillum, with micronutrients) with adequate values of MSPA32, MSR32, CR8 and MSPA8.

Therefore, the results show that the exploratory analyses of the principal components and k-means clustering were efficient and constitute a great tool to classify treatments that evaluate multiple traits, agreeing with several research works that used this technique for studying soybeans. There are reports in the literature stating that multivariate analysis allow identifying with good reliability the most important agronomic traits among many studied traits (Dallastra et al., 2014; Reina et al., 2014 Singh et al., 2020).

\section{Conclusions}

The multivariate analyses discriminate efficiently the different treatments tested.

The cultivars behaved different while the most promising interactions among cultivars, bacteria and micronutrients were observed for the 5D634RR and NS7338 IPRO cultivars in the standard inoculation (Bradyrhizobium, without micronutrients) and co-inoculation (Brady + Azos, without micronutrients) treatments.

In general, cultivars without application of micronutrients were superior in terms of the parameters analyzed.

\section{References}

Araújo, F. D., \& Hungria, M. (1999). Nodulação e rendimento de soja co-infectada com Bacillus subtilis e Bradyrhizobium japonicum/Bradyrhizobium elkanii. Pesquisa Agropecuária Brasileira, 34(9), 1633-1643. https://doi.org/10.1590/s0100-204x1999000900014

Bárbaro, I. M., Bárbaro Junior, L. S., Ticelli, M., Machado, P., \& Miguel, F. (2011). Resultados preliminares da co-inoculação de Azospirillum juntamente com Bradyrhizobium em soja. Apta Regional-Pesquisa e Tecnologia, 8(2), 1-6.

Bárbaro, I. M., Machado, P. C., Bárbaro-Junior, L. S., Ticelli, M., Miguel, F. B., \& Silva, J. D. (2009). Produtividade da soja em resposta à inoculação padrão e co-inoculação. Colloquium Agrariae, 5(1), 1-7. https://doi.org/10.5747/ca.2009.v05.n1.a0040

Brazil. Ministério da Agricultura, Pecuária e Abastecimento. Secretaria de Defesa Agropecuária. (2009). Regras para análise de sementes.

Bohrer, T. R. J., \& Hungria, M. (1998). Avaliação de cultivares de soja quanto à fixação biológica do nitrogênio. Pesquisa Agropecuária Brasileira, 33(6), 937-952.

Campo, R. J., Araujo, R. S., Mostasso, F. L., \& Hungria, M. (2010). In-furrow inoculation of soybean as alternative to fungicide and micronutrient seed treatment. Revista Brasileira de Ciência do Solo, 34(4), 1103-1112.

CONAB (Companhia Nacional de Abastecimento Agrícola). (2019) Sétimo levantamento de grãos (Safra 2018/19). Retrieved from https:/www.conab.gov.br/info-agro/safras/graos

Dallastra, A., Unêda-Trevisoli, S. H., Ferraudo, A. S., \& Di Mauro, A. O. (2014). Multivariate approach in the selection of superior soybean progeny which carry the RR gene. Revista Ciência Agronômica, 45(3), 588-597. https://doi.org/10.1590/S1806-66902014000300021

Döbereiner, J., Baldani, V. L. D., \& Baldani, J. I. (1995). Como isolar e identificar bactérias diazotróficas de plantas não-leguminosas. Embrapa SPI.

Ferraudo, A. S. (2014). Técnicas de Análise Multivariada: Uma introdução. Jaboticabal, SP.

Gitti, D. C., Arf, O., Kaneko, F. H., Rodrigues, R. A. F., Buzetti, S., Portugal, J. R., \& Corsini, D. C. D. C. (2012). Inoculação de Azospirillum brasilense em cultivares de feijões cultivados no inverno. Agrarian, 5(15), 36-46.

Hair, J. F., Black, W. C., Babin, B. J., Anderson, R. E., \& Tatham, R. L. (2009). Análise multivariada de dados. Bookman Editora.

Hungria, M., Campo, R. J., \& Mendes, I. C. (2007). A importância do processo de fixação biológica do nitrogênio para a cultura da soja: Componente essencial para a competitividade do produto brasileiro. Embrapa Soja-Documentos (INFOTECA-E).

Hungria, M., Nogueira, M. A., \& Araujo, R. S. (2013). Co-inoculation of soybeans and common beans with rhizobia and azospirilla: Strategies to improve sustainability. Biology and Fertility of Soils, 49(7), $791-801$. https://doi.org/10.1007/s00374-012-0771-5 
Iqbal, Z., Arshad, M., Ashraf, M., Mahmood, T., \& Waheed, A. (2008). Evaluation of soybean [Glycine max (L.) Merrill] germplasm for some important morphological traits using multivariate analysis. Pakistan Journal of Botany, 40(6), 2323-2328.

Kaiser, H. F. (1958). The varimax criterion for analytic rotation in factor analysis. Psychometrika, 23(3), 187-200. https://doi.org/10.1007/BF02289233

Reina, E., Peluzio, J. M., Afferri, F. S., Oliveira Junior, W. P., \& Siebeneichler, S. C. (2014). Genetic divergence and phosphorus use efficiency in the soybean with a view to biodiesel production. Revista Ciência Agronômica, 45(2), 344-350. https://doi.org/10.1590/S1806-66902014000200016

Santana, M. J., de Sousa, F. C. A., da Silveira, A. L., \& Silva, C. A. (2011). Aplicação de cobalto, molibdênio e inoculante na cultura da soja (Glycine max L. Merrill). Global Science and Technology, 4(2).

Singh, P. K., Shrestha, J., \& Kushwaha, U. K. S. (2020). Multivariate analysis of soybean genotypes. Journal of Agriculture and Natural Resources, 3(1), 69-76.

Statsoft, I. N. C. (2007). STATISTICA (data analysis software system) (Version 10).

Toller, E. V., Bárbaro, I. M., \& Bárbaro-Junior, L. S. (2009). Análise de parâmetros de fixação biológica de nitrogênio em cultivares comerciais de soja. Nucleus, 6(1). https://doi.org/10.3738/1982.2278.135

USDA (Unitad States Departament of Agriculture). (2018). Retrieved from http://usda.mannlib.cornell.edu/ usda/current/worldag-production/worldag-production-09-12-2018.pdf

Zilli, J. É., Ribeiro, K. G., Campo, R. J., \& Hungria, M. (2009). Influence of fungicide seed treatment on soybean nodulation and grain yield. Revista Brasileira de Ciência do Solo, 33(4), 917-923. https://doi.org/10.1590/S0100-06832009000400016

Zuffo, A. M., Bruzi, A. T., de Rezende, P. M., Bianchi, M. C., Zambiazzi, E. V., Soares, I. O., ... Vilela, G. L. D. (2016). Morphoagronomic and productive traits of RR soybean due to inoculation via Azospirillum brasilense groove. African Journal of Microbiology Research, 10(13), 438-444. https://doi.org/10.5897/ AJMR2015.7682

Zuffo, A. M., Rezende, P. M., Bruzi, A. T., Oliveira, N. T., Soares, I. O., Neto, G. F., ... Silva, L. O. (2015). Coinoculação de Bradyrhizobium japonicum e Azospirillum brasilense na cultura da soja. Revista de Ciências Agrarian, 38(1), 87-93.

\section{Copyrights}

Copyright for this article is retained by the author(s), with first publication rights granted to the journal.

This is an open-access article distributed under the terms and conditions of the Creative Commons Attribution license (http://creativecommons.org/licenses/by/4.0/). 